\title{
Legal Aid in Indonesia: A Study of Legal Aid with a Transcendental Dimension
}

\author{
Fanny Dian Sanjaya \\ Mahasiswa Program Doktor IImu Hukum (PDIH) Fakultas Hukum Universitas \\ Muhammadiyah Surakarta \\ fannydiansanjaya@gmail.com
}

DOI: $10.23917 /$ jtl.v2i2.11854

Submission

Track:

Received:

31 July 2020

Final Revision:

21 December 2020

Available online:

29 December 2020

Corresponding

Author:

Fanny Dian Sanjaya

fannydiansanjaya@gmail.com

\begin{abstract}
Legal aid in Indonesia, particularly in terms of access to justice, legal aid provided by the state for people is still pivoted on positive law. Laws regulating legal aid in Indonesia remain revolving around the number of cases and budget absorption targets given to legal aid institutions that have been verified and accredited by the state for people/groups in need. Verification and Accreditation from the state with parameters written in the law inhibit those who need legal assistance if they are not categorized as the poor. The requirement of the poor to access legal aid implies that access to legal aid for everyone in conflict is far from justice. Access to legal aid is essential since the purpose of the law is justice. Besides, legal aid aims to provide justice for those who do not have law knowledge, in other words, blind to the law. Justice for all is the vein of legal aid which is inseparable from the right of legal aid for those in need. Legal aid can be administered by social institutions/legal aid agencies which should provide access to those who need legal assistance and those who are in dispute, be it poor or rich so that justice for all can be achieved. This research discusses the transcendental dimension of legal aid. This study used a descriptive research method intending to analyze legal aid from legal aid institutions viewed from the study of legal philosophy and legal aid with transcendental dimensions.
\end{abstract}

Keywords: Legal Philosophy, Transcendental, Legal Aid 


\section{INTRODUCTION}

The implementation of legal aid in Indonesia is originally targeted those who are economically incapable. Thus, in order to obtain legal aid as stipulated in the legal aid law, every person or group must be categorized as poor. Every person or group who are not the poor cannot access the legal aid budget from the government. Only part of Indonesian people are poor, but many are considered as incapable, weak, oppressed, or very deficient in many aspects but are not administratively poor according to terms, conditions, and parameters that have been determined by the state in the legal aid law.

Legal aid for the poor in legal aid law has not been able to cover the poor, weak and needy or mustad'afin, who struggling before the law and are very in need of legal assistance compared to the poor who are conflicting with the law. Positive law promulgated by the state in the legal aid law should not be separated from humanitarian and justice values, which results in being unable to cover those in need of legal assistance, even though according to the constitution everyone is equal before the law. The concept of free positive law in facilitating those in need and those in trouble is the weakness of the legal aid which cannot provide legal assistance to everyone sociologically in need of legal assistance unless legal aid can only be given to poor people.

Law is very closely related to justice even there is an opinion that law must be combined with justice in order to be truly meaningful as law since the purpose of the law is to achieve a sense of justice in society. In every applicable law, there is a demand for justice. Law without justice will be meaningless and is no longer worth before society. Combining law and justice is easier said than done. Regardless of how difficult it must be, this effort must be done for the sake of the state and jurisdiction as the basic legal rights are recognized by the judiciary (Santoso, 2012, p. 86).

A legal and judicial order cannot be established without regard to justice because justice depicts the true meaning of legal and judiciary. Because the goal of the state and law is to achieve the peak of happiness for its people, yet thinking legal is closely related to the idea of how justice and order can be actualized (Muchsin, 2004, p. 74). Law is formulated as sets of rules consisting of norms and sanctions (Kansil, 1984, p. 38). It must be noted that law is the protection of human interests, while human interests are always developing, dynamic, both its type and quantity. Thus, the law must be dynamic to be parallel with the development of human 
interests so that the ever-developing human interest can always be protected (Mertokusumo, 2014, pp. 25-26).

The weaknesses in legal positivism insulate normative truth, as well as criticism of sociological legal thinking (quantitative and interpretative), although at a certain point is valuefree, understands reality and leaves it as is, and does not take sides. It encourages some people to present legal science that supports humanitarian goals as a critical theory so that legal science does not only serve the interests of the status quo behind its value-free claims but something beyond that (Putro, 2011, p. 1).

Laws that are only formed in the realm of mere logic will become a problem because the norms established by it solely rely on human reason. In these circumstances, the norms that will be built will conflict with the actual norms. As the norm of justice will conflict with positive legal norms, a difference between the real value of justice and the legal that is built will eventually emerge. Since positive legal norms are formulated based on human reason, it is impossible to fully reflect the actual reality, thus uprising values in the realm of metaphysical and rational values (Kusumohamidjojo, 2011, pp. 143-144).

Meanwhile, according to Teguh Prasetyo in his book entitled 'Keadilan Bermartabat Perspektif Teori Hukum' (Dignified Justice with the Perspective of Legal Theory) states that the law to create a dignified society is the law - including in this case is regulation of legal aid for those in need - humanizing human. It articulates that the law treats and upholds human values according to the nature and purpose of life. Human beings are noble creatures of God as stated in the second principle of Pancasila, just and civilized humanity, which contains a recognition of human dignity with all rights and obligations he entails as well as obtaining just treatment of humans, oneself, surrounding and God (Prasetyo, 2015, p. 109).

Efforts to discuss issues of law, religion, ethics, and morals deeply will support the results of the development of legal science. Therefore, to study and understand the law, one must emphasize more on substantial and transcendental matters with the ground of social facts that are inseparable from religious, ethics, and moral values (Absori, 2005). To achieve the ideal law, humans are required to always think - coqito ergo sum - I think therefore I am. Thus, Rene Descartes poetically philosophizes about the existence of a human being (Islami, 2015, p. 1). The essence of human beings is to think because it is the superiority of humans and the ability to think is only possessed by humans, not by other living things (Asy'arie, 2016, p. 1). 
Legal aid in a dignified society shall emerge as a manifestation of human and justice values that are absorbed and regulated in the legal aid law so that everyone can access legal aid from the state. Legal aid for poor people stipulated in the law does not cover those who are incapable, weak, and needy or mustad'afin, disputing before the law, thus losing its core as a means of helping those in need. Surah An - Nisa verse 75 which translates " And what is [the matter] with you that you fight not in the cause of Allah and [for] the oppressed among men, women, and children who say, "Our Lord, take us out of this city of oppressive people and appoint for us from Yourself a protector and appoint for us from Yourself a helper!”. Weak people are not merely economically incapable but can be in form of discrimination and oppression. Hence, defending in the sense of providing legal aid for weak people and those in need of legal assistance is a call to perform Allah's orders. " By the 'passage of' time!. Surely humanity is in 'grave' loss, except those who have faith, do good, and urge each other to the truth, and urge each other to perseverance." (Surah Al-Ashr: 1-3). Carrying out Allah's order to do righteous deeds, advice to obey the truth, and advice to be patient is a transcendental legal concept.

Transcendental law in the development of legal science highlights the integration between law and religion which occupies science according to the postmodernism movement. In this case, science is understood in a wider range, encompassing ethical, moral, and spiritual values of religion. It is where religion plays an important role in the effort to understand the law and legal science in a broad or holistic perspective. From a historical perspective, postmodern law offers spiritual value as a result of the spiritual crisis in modern law. The law offered emphasizes law not only formal and procedural but more extended with the unity of knowledge which connects law with empirical facts and the entailed values include ethical, moral, and spiritual values (Absori, 2015, pp. 34-49 ).

Kuntowijoyo's idea of reintegrating science and religion led to the concept of prophetic science. The prophetic paradigm comprises four important values as its foundation; humanization, liberation, transcendence, and historical activism. These four values, apart from being a critical framework, also underlie the idea of emancipation - from individual transformation through faith and humanization, to the transformation of science through the liberation of Islamic knowledge and scholarship, to social transformation with historical activism. Thus, the interests of the prophetic paradigm are humanization, liberation, and 
transcendence as well as freedom in historical activism, which are unbounded to contribute and not forced to do something (Absori, Wardiono, and Rochman, 2015, p. 1).

According to the Great Dictionary of the Indonesian Language of the Language Center, transcendental is: 1. to emphasize spiritual matters; 2 elusive; 3 invisible; 4 abstract, so the law in this theory is based on spiritual values that are elusive and abstract (kemdikbud.go.id, 2020). Transcendental law cannot be separated between its physical bodies (formal) and transcendental values. The only pursued justification for transcendental law is for the sake of justice based on the truth under the power of Allah, the Almighty, the controller of life (Absori, 2017, p. 32).

Given the explanation above, the authors are interested in examining legal aid in a transcendental dimension. Transcendental as Kuntowijoyo's perception is based on three aspects; humanization (amar ma'ruf), liberation (nahi Munkar), and transcendence (faith). These three points are the concept of legal aid which is expected to provide justice for all based on human values.

\section{FORMULATION OF THE PROBLEM}

1. How is the implementation of legal aid in positive law in Indonesia?

2. How is the concept of legal aid with a transcendental dimension?

\section{RESEARCH METHODS}

The method of this writing is descriptive research. This research attempts to describe the variables under study independently, with no association with other variables, either comparing or connecting. Besides, this research was also conducted using a philosophical approach. Secondary data used in this paper were document studies in the form of experts' opinions (doctrine) written in books as well as books in legal philosophy setting (Shidarta, 2006, pp. 30-32).

\section{Legal Aid in Indonesia}

Legal aid should be the right for all Indonesian people, regardless of rich or poor, capable or incapable, strong or weak, even the majority or minority, so that the state shall 
protect the whole people of Indonesia and the entire homeland of Indonesia and in order to advance general prosperity, to develop the nation's intellectual life, and to contribute to the implementation of a world order based on freedom, lasting peace, and social justice as expressed in the Preamble to the 1945 Constitution of the Republic of Indonesia. Protection for all Indonesian people is also inseparable from the right of Indonesian citizens to obtain legal aid under no term. Article 27 paragraph (1) of the 1945 Constitution states "All citizens have equal status before the law and in government and shall abide by the law and the government without any exception". It affirms that there is no difference in obtaining the right to legal aid for Indonesian citizens. However, in its elaboration, as stipulated in the legal aid law, it states that legal aid is provided free of charge to people or groups of poor, as stated in Article 1 number 1 and Article 1 number 2 of Law Number 16 of 2011 on Legal Aid.

Legal aid for the poor obliterates the right of those in need of legal assistance, mustad'afin, needy, incapable, minority, and even those who are conflicting with the law from their right to obtain legal aid from the state if they cannot prove their requirements as the recipient. The parameters determined by the state for those categorized as poor are also insufficient in the implementation so those are unable to reflect the values of justice and humanity promulgated in the legal aid law. Recipients of legal aid are considered as the poor as long as they can prove the administrative requirements. The data on legal aid recipients further are presented in sidbankum chart accessed on March 11, 2020, as follows:

Chart data below are from 2020 to 11 March 2020

Statistic Report of Legal Aid Recipients (Based on Occupation) 

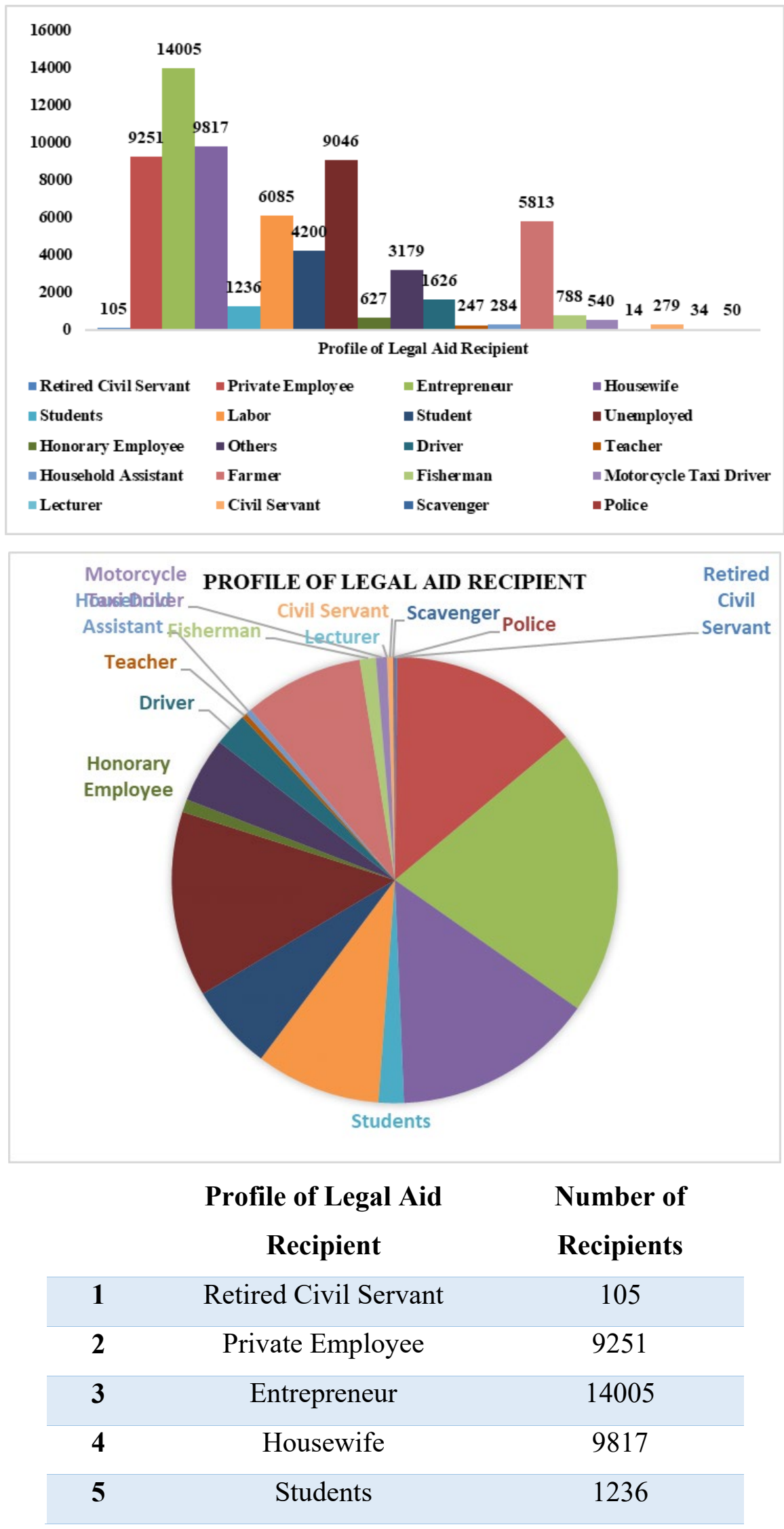


\begin{tabular}{|ccc|}
\hline $\mathbf{6}$ & Labor & 6085 \\
\hline $\mathbf{7}$ & Student & 4200 \\
\hline $\mathbf{8}$ & Unemployed & 9046 \\
\hline $\mathbf{9}$ & Honorary Employee & 627 \\
\hline $\mathbf{1 0}$ & Others & 3179 \\
\hline $\mathbf{1 1}$ & Driver & 1626 \\
\hline $\mathbf{1 2}$ & Teacher & 247 \\
\hline $\mathbf{1 3}$ & Household Assistant & 284 \\
\hline $\mathbf{1 4}$ & Farmer & 5813 \\
\hline $\mathbf{1 5}$ & Fisherman & 788 \\
\hline $\mathbf{1 6}$ & Motorcycle Taxi Driver & 540 \\
\hline $\mathbf{1 7}$ & Lecturer & 14 \\
\hline $\mathbf{1 8}$ & Civil Servant & 279 \\
\hline $\mathbf{1 9}$ & Scavenger & 34 \\
\hline $\mathbf{2 0}$ & Police & 50 \\
\hline
\end{tabular}

Sidbankum Data Chart (bphn.go.id, 2020)

Based on the data on legal aid recipients that have been grouped based on occupation above, there is a wide range of occupations of legal aid recipients, from retired civil servants, civil servant, teacher, police, lecturer, to fishermen, motorcycle taxi driver, farmer, driver, scavenger, household assistants, student, labor, entrepreneur, private employee, honorary employee, and so on. Thus, it is very difficult to conclude that the recipients of legal aid are poor people or groups of poor people. Poor people do not have the income to meet their basic needs. Retired civil servants, civil servants, teachers, police as well as lecturers certainly have a steady income and can meet their basic needs. Obviously, it is unfair for those who cannot afford to deal with the law. Indeed, they need legal assistance yet are not considered as poor.

The right of legal aid, which is limited to a person or group of poor people, is contrary to the objectives of the legal aid law itself as stated in Article 3 letter $b$ "to realize the constitutional rights of all citizens according to the principle of equality before the law". The principle of equality before the law in the context of legal aid rights limited to the poor cannot ensure the rights of all citizens who need legal assistance, including mustad'afin or those in 
need of legal aid, as long as those disputing in law are weak, oppressed, poor, and marginalized and are not pronounced as the poor by the state.

The meaning and purpose of legal aid are different in each era as regulated in the prevailing laws and regulations. In general, legal aid is aimed at everyone who is incapable on humanity base. In the Dutch colonial era, legal aid was regulated in the Herzien Inlandsch Reglement (HIR) Indonesian Revised Reglemen (RIB) in article 250 which says "If the accused is ordered to appear before a judge for a crime punished by the death sentence, and the accused, both in examination by the prosecutor stipulated in paragraph six of article $83 \mathrm{~h}$, later states his/her wish thus during the trial is assisted by a legal scholar or a legal expert, so to provide such assistance, the chairman in his decree appoints a member of the district court, a legal expert, or an employee with a legal degree or other legal experts who agree to carry out the job. The appointment may also be made by means of a segregated decree as long as the examination at the trial has not yet been completed if the suspect expresses such an intention. However, the appointment does not occur if there is no employee of a law degree or legal expert at the district court who agree, thus an employee of a law degree or other legal expert appointed by district court shall provide legal aid free of charge." Free legal assistance is only for those with a death sentence under the note that the legal assistant agrees to do so.

In 2003, along with the promulgation of the law on advocates in Law Number 18 of 2003 in Article 1 number 9, it says that Legal Aid is legal services provided by advocates free of charge to those who cannot afford it. In 2011, the legal aid law was enacted. Legal aid is a service provided by legal aid providers free of charge to recipients as stated Article 1 number 1 of Law Number 16 of 2011 on Legal Aid. The right to legal aid has been universally accepted as guaranteed in the International Covenant on Civil and Political Rights (ICCPR). Articles 16 and 26 of the ICCPR guarantee that all people have the right to legal protection and must be protected from all forms of discrimination. Meanwhile, Article 14 paragraph (3) of the ICCPR provides conditions related to Legal Aid: 1) the interests of justice, and 2) the inability to pay Advocates. The free legal aid provided by legal aid institutions/community organizations including advocates is free, meaning that legal aid recipients do not pay a penny in obtaining free legal aid as their right.

The right to legal aid is also contained in Article 18 of Law Number 39 of 1999 on Human Rights Article 18 paragraph (4) that everyone brought before a tribunal has the right to 
legal aid from the start of the hearing until a legally binding decision is made by the tribunal and Article 54 of Law Number 8 of 1981 on Criminal Procedure Law that for purposes of defense, a suspect or an accused shall have the right to obtain legal assistance from one or more legal counsels during the period of and at every stage of examination, according to the procedures stipulated in law this and Law Number 48 of 2009 on Judicial Powers in Article 56 paragraph (1) states that every person who snagged the matter entitled legal aid and paragraph (2) the State bears the costs of litigation for seekers of Justice who couldn't afford it, so whether in the Criminal Procedure Law and the Judicial Power Law, this assistance is the right of everyone and the state bears the costs for justice seekers who cannot afford nor are they limited by the poor condition to be entitled to legal aid.

\section{Transcendental Dimensions of Legal Aid}

Nowadays, legal problems are increasingly complex, technological and scientific are developing, the poverty rate has decreased along with reform. The vast majority of Indonesian people are no longer poor. Communities with a middle-income economy who are not poor or those that are unable to pay for advocate services, oppressed, marginalized, and minorities do not obtain legal assistance from the state when conflicting with the law while they require legal aid. Thus, the concept of pro bono legal aid emerges, which is an obligation for advocates to carry out their legal aid obligations. The concept of pro bono legal aid is aimed at those in need of legal assistance but cannot afford the services of a lawyer. Then for those who are considered poor based on administrative, the concept of state legal aid for the poor appeared. It means that legal assistance is provided to the poor with the budget from the state, not directly from lawyers or legal aid institutions.

According to Schuyt, Groenendijk, and Sloot as quoted by Soerjono Soekanto in his book entitled “Bantuan Hukum Suatu Tinjauan Sosio Yuridis' (Legal Aid: A Socio-Juridical Review), there are five types of legal aid: (Soekamto, 1983, p. 27)

1. Preventive legal aid ("preventive rechtshulp") is legal information and legal counseling to the wider community.

2. Diagnostic legal aid ("diagnostic rechtshulp") is the legal advice commonly called legal consultation. 
3. Legal aid for conflict regulation ("conflictregulerend rechtshulp") is legal aid to address concrete legal problems (Note: this legal assistance is known as "legal aid" for underprivileged or poor citizens, socially and economically)

4. Legal aid for law formation ("rechtsvormende rechtshulp") is to provoke firm, accurate, clear, and correct jurisprudence.

5. Legal aid for law reform ("rechtsverniewende rechtshulp") includes efforts to enforce legal reforms through judges or legislators (in the material setting).

Based on the aforementioned types of legal aid, the concepts of legal aid emerge. The existing concepts of legal aid, such as structural legal aid, pro bono legal aid, and free legal aid, are no longer able to cover those in need of legal aid. The concept of structural legal aid, for instance, was motivated by the fact that the vast majority of citizens at that time were poor and did not understand the law. Most of these poor people could not participate in the political and economic role, resulting in a gap between the majority of the poor and the powers that existed at that time, resulting in unequal relationships.

The concept of structural legal aid according to Adnan Buyung Nasution implies a series of programs, either through legal means or other acceptable methods that are directed towards changes in the relationships which will be the basis of social life towards a more equal relationship. It is a prerequisite for developing laws that provide justice for the majority of the poor in Indonesia. It means that the concept of structural legal aid is developed in the context of building a just and prosperous society (Nasution, 1981, pp. 292-293).

Legal aid activities in Indonesia vary, though they are specifically defined as advocate activities in the course of litigation. Legal aid is one of the organizations in the legal system that carries out practical legal development. If in the judicial setting, the judge is the key figure who will give the final decision and within the legal aid organization lawyers/advocates offer alternative reasoning outside those proposed by their fellow lawyers or advocates from the opposing party (in civil/state administrative cases) or by prosecutors (in criminal cases) (Shidarta, 2013, pp. 291-293).

The existence of legal bearers is fundamental in law enforcement, they must find the right, civilized, and fair legal decisions. Legal bearers are not justified to only look at articles as the considerations, but also must examine the social and human dimensions within a case. In theory, it must have a starting point, which is the relationship between humans and law. The 
more deteriorated the theoretical basis to the regulation, the more it will be considered as a formal-legalistic closed unit. Conversely, the more the theory shifts to humans, the more it opens and touches the social issue of humanity (Putro, 2011, p. 1).

In an article entitled "Legal Aid: Modern Themes and Variations", Cappelletti and Gordley describe several legal aid systems, both in Europe and in America. They state that there are two models (systems) of legal aid, which are then called juridical- individual model and welfare model. It means that on the one side legal aid can be perceived as a right bestowed to citizens to protect individual interests and, on the other side, as a right to welfare which is part of the social protection framework provided by a welfare state (Soekamto, Op.Cit, p. . 11).

Everyone has the same right to obtain legal aid, to obtain justice because it has been guaranteed by the 1945 Constitution. This right for everyone is called welfare. Legislations on legal aid should provide justice in terms of access to legal aid which is a right for everyone, under no distinction in social status, to protect all. Moreover, legal aid is a right for those in need. It is considered as justice if legal aid as a right is provided by the state to legal aid recipients under no poverty condition as regulated in the legal aid law. Legal aid providers are social institutions or legal aid institutions. In Islamic community organizations, for instance, the perspective used is unlike legal aid in the existing positive law. The concept of legal aid, in general, is to assist those in need of legal assistance and, in particular, Muslims who are disputing so that truth and justice can be upheld. Legal aid also functions to provide legal assistance to members of the organization, including providing legal assistance to the assets of social organizations which then become disputes or objects of disputes in law at any level.

Based on the concepts of legal aid above, such as structural legal aid, pro bono legal aid, free legal assistance, it is evident that there is a shift in the need for legal aid that is not accessible to existing legal aid, even its definition and objectives have begun shifting. In the past, structural legal aid was aimed at the poor. The pro bono legal aid for the poor was based on an advocate's subjective assessment and free legal aid for the poor used state funds. This shift occurred due to the legal aid required today not only for the poor but also for everyone who conflicts with the law. The criteria for legal aid recipients, the background of providing legal aid, the objectives of legal aid, the budget for legal aid are no longer determined solely by-laws regulating existing legal aid but also a form of obligation to facilitate human beings on the ground of values of ethics, moral, and spiritual or transcendental. 
Beyond that, the law is attached to the entity of faith: belief in God, as at the beginning of a Law is always written the words "By the Grace of God Almighty", or in Judicial Decision in Court saying "For the Justice, belief in one and only God". It has raised the perception that law is identical not only to justice but also to the sacredness of "Divinity". Yet, in the end, we are trapped in the reality that we construct as paradoxical when looking at that the law does not represent justice or even divinity (Cahyadi, 2009, p. 290).

The development of the need for legal aid in Indonesia has resulted in a new dimension of legal aid, which is legal aid in a transcendental dimension. It occurs because available legal aids, such as structural legal aid, free legal aid, and pro bono legal aid, are no longer able to embrace those in need. Legal aid for those who are not poor has created and mobilized Islamic social organizations to assist the state in providing legal aid. Legal aids provided by Islamic community organizations are those with a transcendental dimension. The transcendental dimension of legal aid arises because the law cannot cover the need for legal aid. The concept of legal aid also uses an approach of ethical, moral, and spiritual values which should be the source of the laws governing legal aid.

Since the very beginning, legal aid has had a transcendental dimension since legal aid has been aimed at helping those in need of help. This assistance is provided by legal aid providers such as legal aid institutions and community organizations. Facilitation either from society organizations or from legal aid institutions is technically carried out by advocates. Advocates have a professional code of ethics in carrying out their profession. Besides, advocates take an oath or swear to respective belief before carrying out their profession to help those in dispute and need of legal aid. The oath or swear of an advocate before carrying out his profession, including providing legal aid, is pronounced with "In the name of Allah I swear/I promise", making this legal aid a transcendental dimension from the start. Advocates who have sworn and promised their God before carrying out their profession of providing legal aid become part of social organizations or legal aid institutions that perform legal aid. The Oath or Swear of Advocates to God embodies a transcendental dimension in carrying out professional duties including providing legal aid. They will always act honestly, fairly, and responsibly according to the law and justice because oaths/promises receive direct spiritual supervision from God.

The transcendental dimension of legal aid provided by Islamic social organizations, for instance in providing legal aid, is based on values of human and justice with no condition that 
indicates that the recipient is poor. Muhammadiyah Organization provides legal aid to its members, mustad'afin, Muslims, or anyone who are in need through the Legal Aid Institute under the Muhammadiyah Higher Education as a form of community service and through the Muhammadiyah Legal Aid Institute as a form of implementing Qur'an and Sunnah of the Prophet. Legal aid provided to its members, fellow Muslims or mustadafin, is not merely for those in need but is based on moral and spiritual values in practicing religion and the obligations of Allah and the Prophet.

The Muhammadiyah Legal Aid Institute was formed to create legal order in the nation and state, ensure justice and human values inside and outside Muhammadiyah setting. Basic Legal Aid Services in Law and human rights are organized based on the values derived from the Qur'an and Sunnah of the Prophet as well as Muhammadiyah regulations. The principles of legal aid services are carried out with the principles of justice, advance, sincerity, honesty, trustworthiness, professionalism, transparency, accountability, caring for the poor, and a balance that combines knowledge, faith, and charity (Decree of the Law and Human Rights Council Number 01/I. 11/I/2020).

The concepts of legal aid for the Islamic Community Organization and Muhammadiyah Organization which have the Muhammadiyah Legal Aid Institute use the concept of legal aid with a transcendental dimension in giving legal advice. Muhammadiyah is a legal entity organization which is also an Islamic movement, Da'wah Amar Ma'ruf Nahi Munkar (commanding the good and forbidding the evil) and Tajdid (renewal), according to the Qur'an and Sunnah. So the concept of legal aid is also sourced from the Qur'an and Sunnah of the Prophet. Legal aid given is such as "Constitutional Jihad" and "Humanitarian Jihad" (jihad means struggling) so it is legal aid with a transcendental dimension.

According to Roger Garaudy, transcendental or transcendence is interpreted in three perspectives; first, acknowledging human dependence on the Creator. The attitude of being satisfied with oneself and looking at humans as the center and measure of everything is contrary to transcendence. Transcendence overcomes human instincts, such as greed and lust for power. Second, transcendence means acknowledging the continuity and common measure between God and human beings, implying that transcendence is parallel to power, wealth, and knowledge. Third, transcendence means acknowledging the superiority of absolute norms that transcend human reason (Fahmi, 2005, p. 97). 
Transcendental thought can be viewed in a wider range, in the form of spiritual, ethical, and moral. Spiritual, ethics, and morality are no longer understood in one aspect, which are aspects connected to theological issues and desires that are visible through doctrines and prays, but more than that. Issues of these values can converse with the development of science, social, culture, economics, and law. Transcendental scholars proposed values and meanings behind it so that it appears that the building of knowledge is more open and complete in responding to the problems of life. In this case, transcendental thought begins to talk irrational and metaphysical (emotions, feelings, intuition, values, personal experience, speculation), moral, and spiritual aspects as part of understanding science (Absorb, Op.Cit, p. 15).

Muhamadiyah has a role in providing legal aid as a call of Allah for the sake of humanity and justice without the conditions referring to an individual as the poor. Muhammadiyah defends mustad'afin with humanitarian jihad in handling cases or with constitutional jihad at the level of judicial review through the Muhammadiyah Legal Aid Institute/Legal Aid Institution under Muhammadiyah Higher Education. Legal aid is provided not only because they deserve legal aid but is based on moral and spiritual values in practicing religion and God's orders to humanize humans by doing righteous deeds, giving advice to obey the truth, and uphold justice on earth. Allah teaches to help those destitute or poor with the existence of zakat from the material. So, the first concept of helping human beings, Muslims in solving legal problems by means of legal aid are also helping from the immaterial side. The second concept is along with the time, many other Islamic social organizations have provided legal aids to other Muslims, Islamic figures/activists, members of social organizations who are in conflict, assets belonging to Islamic social organizations that are in dispute, as well as the ground of the Islamic organization itself if there is a change in the prevailing laws and regulations. Cases that have come to the public's attention, such as the 212 Movement (Action to Defend Islam) due to blasphemy of the Quran, Death of the Suspected Criminal Act of Terrorism Alm. Siyono prior to the trial process, and the Imam of the Islamic Defenders Front, require an approach with a transcendental dimension in providing legal aid.

The concept of legal aid with a transcendental dimension is legal aid to everyone in need as a manifestation of the absorption of spiritual and ethical values. Justice and humanity are the core of transcendental law which is implemented in legal aid. Legal aid is provided to anyone, including the mustad'afin, the poor, the minority, and the marginalized, not limited to 
the course that rights of legal aid only to people or groups of poor people as regulated in the legal aid law. Transcendental legal aid does not only humanize humans by providing legal aid rights as the main effort when dealing with the law but also contains humanitarian and justice objectives. The ethical, moral, and spiritual values of religion in legal aid are expected to be more capable of providing justice. Implemented humanitarian and fair legal aid will provide its own spirit for legal aid actors because it embodies the orders of Allah to help other human beings through legal aid and do justice by providing legal aid to those in need.

\section{CONCLUSION}

The implementation of legal aid in Indonesia still refers to positive law, which only provides it to the poor. Yet, in its practice, it happens that not only poor people can access legal aid, resulting in legal aid as regulated in the legal aid law becoming ineffective. Legal aid is a right that must be given to all people who are in conflict with the law regardless of status; rich, incapable, oppressed, marginalized, or poor so that it is fair for every Indonesian who faces the law, be it plaintiffs, defendants, victims, witnesses, or perpetrators. To understand legal aid, its substance must be examined in-depth, which is inseparable from spiritual, ethical, and moral values. Legal aid contains the essence of assisting other human beings who are experiencing legal difficulties or dealing with the law. Law is a primer in nature. Everyone in conflict with the law aims to seek justice. Justice is a basic human need that is desired by everyone regardless of the status of rich or poor. Justice is the main aspect of human needs, as stated by Daniel Webster "Justice is the great interest of men earth". God teaches human beings through His Prophet and his Apostles to help other human beings who are in dispute. Finally, the concept of legal aid containing a transcendental dimension to all people is attached to transcendental values and can be applied in legal aid in Indonesia. The concept of legal aid with a transcendental dimension is a concept currently needed to complete the concept of Individual legal aid, structural legal aid, pro bono legal aid, and existing legal aid for groups/poor people. 


\section{REFERENCES}

Absori, Hukum Dan Dimensi Spiritual: Perspektif Positivis, Pospositivis dan Spiritualisme, dalam PROFETIKA, Surakarta: Magister Pemikiran Islam Program Pascasarjana Univesitas Muhammadiyah, Jurnal Studi Islam Vol. 7 No. 2 Tahun 2005

Absori, Epistimologi Ilmu Hukum Transendental dan Implementasinya dalam Pengembangan Program Doktor Ilmu Hukum, Proseding Seminar Nasional Pengembangan Epistimologi Ilmu Hukum, Program Doktor Ilmu Hukum Universitas Muhammadiyah Surakarta, 2015

Absori, "Pemikiran Hukum Transendental dalam Konteks Pengembangan Ilmu Hukum Indonesia," dalam Transendensi Hukum Prospek dan Implementasi, Yogyakarta: Genta Publishing, 2017

Absori, Kelik Wardiono, Saepul Rochman, Hukum Profetik: Kritik Terhadap Paradigma Hukum Non Sistematik, Yogyakarta: Genta Publishing, 2015

Adnan Buyung Nasution, Bantuan Hukum Di Indonesia, Jakarta: LP3ES, 1981

Antonius Cahyadi, Hukum Sebagai Teks: Penanda Yang Kosong, dalam Sosiologi Hukum dalam Perubahan, Jakarta: Yayasan Obor Indonesia, 2009

Budiono Kusumohamidjojo, Filsafat Hukum: Problematik Ketertiban yang Adil, Bandung: Mandar Maju, 2011

C.S.T. Kansil, Pengantar Ilmu Hukum Dan Tata Hukum Indonesia, Jakarta: Balai Pustaka, 1984

Ketentuan Majelis Hukum dan Hak Asasi Manusia Nomor 01/I.11/I/2020, Muhammadiyah, 2020

M. Agus Santoso. Hukum, Moral Dan Keadilan: Sebuah kajian Filsafat Hukum, Jakarta: Prenadamedia Group, 2012.

Muchsin, Kekuasaan kehakiman Yang Merdeka Dan Kebijakan Asasi. Jakarta: STIH IBLAM, 2004

M. Fahmi, Islam Transendental, Menelusuri Jejak Jejak Pemikiran Islam Kuntowijoyo, Yogyakarta: Pilar Religia, 2005

Muhammad Nur Islami, Hukum Dan Kebebasan Berpikir, Yogyakarta: Pustaka, Pelajar Offset, 2015

Musa Asy'arie, Rekontruksi Metodologi Berpikir Profetik, Yogyakarta: Lembaga Studi Filsafat Islam (LESFI), 2016

Shidarta, Karakteristik Penalaran Hukum dalam Konteks Keindonesiaan, Bandung: CV Utomo, 2006

Shidarta, Hukum Penalaran dan Penalaran Hukum, Yogyakarta: Genta Publishing, 2013

Soerjono Soekamto, Bantuan Hukum Suatu Tinjauan Sosio Yuridis, Jakarta:Ghalia Indonesia, 1983

Sudikno Mertokusumo, Teori Hukum, Yogyakarta: Cahaya Atma Pustaka, 2014

Teguh Prasetyo, Keadilan Bermartabat Perspektif Teori Hukum, Bandung: Nusa Media, 2015

Widodo Dwi Putro, Kritik Terhadap Paradigma Positivisme Hukum, Yogyakarta: Genta Publising, 2011

Kamus Besar Bahasa Indonesia on line, https://kbbi.kemdikbud.go.id/entri/transendental, diakses tanggal 1 Juni 2020

SID Bankum - BPHN, https://sidbankum.bphn.go.id/, diakses pada tanggal 11 Maret 2020 